\title{
Seasonal Movements and Home Ranges of Feral Horse Bands in Wyoming's Red Desert
}

\author{
RICHARD MILLER
}

\begin{abstract}
Feral horses have seasonal movement patterns which correspond to their use of water sources and areas near ridges. Home ranges of horse bands varied in size from 73 to $303 \mathrm{~km}^{2}$. Some bands shared use of a common home range. Those bands having a common range followed similar movement patterns within their home ranges. $A$ herd is defined as a structured social unit made up of bands following movement patterns within'a common home range.
\end{abstract}

Movements of feral horses can be important to managers in determining the effects of the horses on the range and in setting boundaries of herd management units. Previously reported feral horse home ranges have varied from $0.9 \mathrm{~km}^{2}$ on Sable Island (Welsh 1975) to $78 \mathrm{~km}^{2}$ for a spring and summer home range in Stone Cabin Valley, Nev. (Green and Green 1977). As part of a general study of feral horses in Wyoming's Red Desert (Miller and Denniston 1979, Boyd 1980, Miller 1980, Miller 1981, Miller 1983), movements and home ranges of the horses were determined. The objectives of this portion of the study were to determine the size of band use areas and to determine if a pattern existed in time of use for any one area.

\section{Methods}

Research was begun in June 1976 and continued until September 1979. Bands were identified with a photo file and card file system keyed on color combinations and readily identifiable individual horses. When bands were identified their locations were plotted to quarter section of USGS to topographic maps. Bands were located from the ground using binoculars and a spotting scope. A number of locations were obtained while working on other portions of the study, such as while following breeding horses. When a band had not been located for 2 weeks, the known use area of that band and adjacent areas were searched. Between November 1977 and April 1979 bands were also located from an airplane during 16 flights made to study habitat use of feral horses and cattle (Miller 1983).

\footnotetext{
Author is formerly graduate student, Department of Zoology and Physiology, University of Wyoming Laramie 82071, and presently Wildlife Specialist 11, Arizona Game and Fish Department, 2222 W. Greenway Rd., Phoenix 85023.

The author thanks Lee Boyd, Val and Ray Hobbs and R.H. Denniston Il for their help. Flight time was paid for by: The International Society for the Protection of Mustangs and Burros; Wild Horse Organized Assistance; The Rock Springs District of the Bureau of Land Management; the Department of Zoology and Physiology of the University of Wyoming; Mrs. Margaret Haggard, Mr. and Mrs. C.T. Mallory; R.H. Dennision II; Lee Boyd and Ann Miller.
}

In determining home ranges I modified Mohr's (1974) minimum home range method in that 2 outside points were not connected if the area which would be included was easily observed and regularly covered during field work. Any band using such an area should have been easily spotted. I made this modification to avoid inflating home range estimates.

\section{Results}

Only one of the home ranges I determined in the Red Desert fell within the range of previously reported sizes $\left(0.9 \mathrm{~km}^{2}\right.$ to $\left.78 \mathrm{~km}^{2}\right)$ (Welsh 1975, Green and Green 1977). Most home ranges were larger than any previously reported (Table 1). Locations and identification of bands was much more difficult during winter, as bands were much more wary in winter. A band which we could regularly approach within $\mathbf{4 0 0} \mathrm{m}$ in the summer often could not be approached within $1 \mathrm{~km}$ in winter. This wariness, combined with limited access to the area and fewer field days available during fall and winter, limited the number of fall and winter locations.

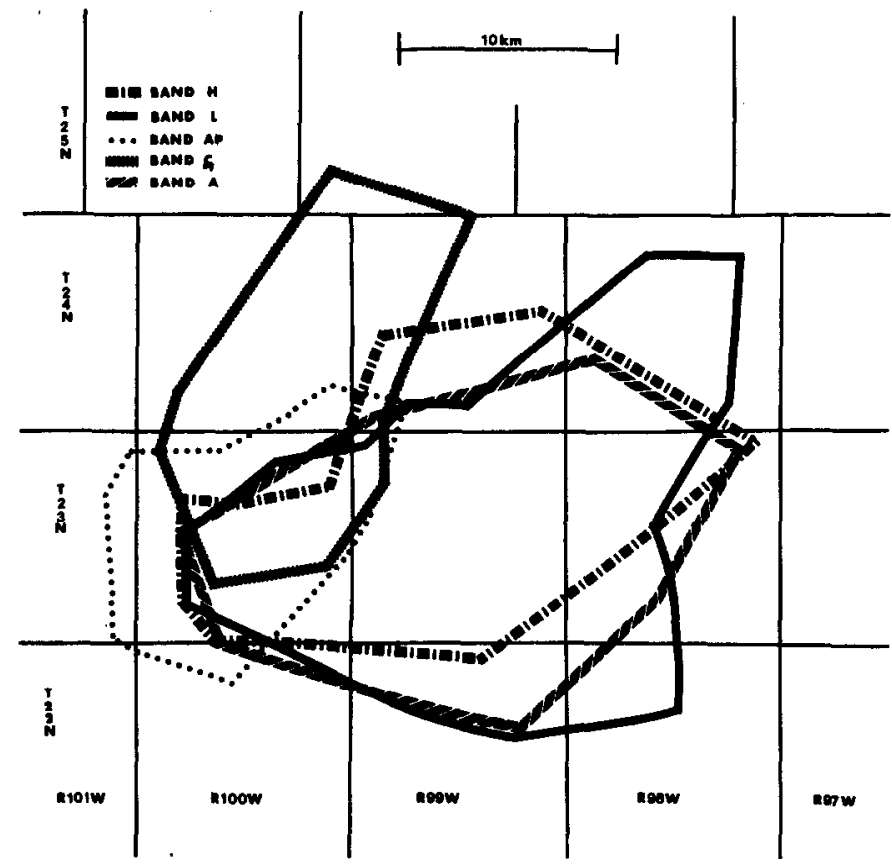

Fig. 1. Home ranges of Bands $A, H$, and $L$ from Herd \#I and Bands $A P$ and $C Z$ from other herds. 
Table 1. Home ranges of feral horse bands in Wyoming's Red Desert.

\begin{tabular}{|c|c|c|c|c|c|c|c|}
\hline \multirow[b]{2}{*}{ Band } & \multirow{2}{*}{$\begin{array}{l}\text { Home range } \\
\text { size }\left(\mathrm{km}^{2}\right)\end{array}$} & \multirow{2}{*}{$\begin{array}{l}\text { Part of } \\
\text { herd \#1 }\end{array}$} & \multirow[b]{2}{*}{ Dates } & \multicolumn{4}{|c|}{ Number of locations by season } \\
\hline & & & & Dec.-Mar. & Apr.-May & June-July & Aug.-Nov. \\
\hline A & 264 & yes & $8 / 76-2 / 79$ & 5 & 8 & 26 & 19 \\
\hline B & 197 & yes & $8 / 76-7 / 79$ & 2 & 14 & 28 & 16 \\
\hline $\mathrm{N}$ & 233 & yes & $8 / 76-9 / 79$ & 6 & 12 & 52 & 22 \\
\hline $\mathbf{L}$ & 303 & yes & $6 / 76-8 / 79$ & 5 & 40 & 67 & 19 \\
\hline $\mathrm{Y}$ & 73 & no & $8 / 76-10 / 79$ & 1 & 6 & 51 & 16 \\
\hline $\mathrm{AC}$ & 158 & yes & $4 / 77-10 / 79$ & 1 & 2 & 58 & 6 \\
\hline $\mathrm{AE}$ & 88 & $?$ & $6 / 77-8 / 79$ & 0 & 4 & 33 & 8 \\
\hline AP & 101 & no & $6 / 77-9 / 79$ & 0 & 10 & 57 & 9 \\
\hline $\mathrm{CV}$ & 166 & yes & $10 / 77-10 / 79$ & 0 & 7 & 29 & 9 \\
\hline $\mathrm{CZ}$ & 145 & no & $5 / 77-7 / 79$ & 1 & 7 & 30 & 15 \\
\hline$\overline{A L}$ & 93 & no & $8 / 76-7 / 79$ & I & 7 & 40 & 13 \\
\hline
\end{tabular}

The home ranges of some horse bands in the Red Desert overlap almost completely (Fig. 1, Bands A, H and L), and I believe these bands can be said to have a common home range. Bands with a common home range follow similar movement patterns within that home range. An illustration of this is that bands with similar movement patterns were often first located and last located near a partcular well or foraging site with a few days of each other (Table 2).

Figure 1 illustrates home ranges for bands from more than one herd and shows that herd home ranges do overlap. Association of bands from different herds is not unusual at a water source or feeding site. All bands from one herd do not always move at the same time but usually follow similar patterns in their movements and usually move as groups of bands (Table 2).

Bands of horses followed very similar movement patterns each year of the study, arriving in a portion of their home range at approximately the same time each year. In effect, they followed something similar to a rotation grazing system in which the same pasture is used at the same season each year. A composite of the seasonal locations of 6 bands which had overlapping home ranges and similar movement patterns (Fig. 2) shows discrete winter and summer seasonal use a reas, indicating the similarity in movements and habitat selection. The large sizes of the April-May and the August-November seasonal ranges (Fig. 2) reflect the variation in

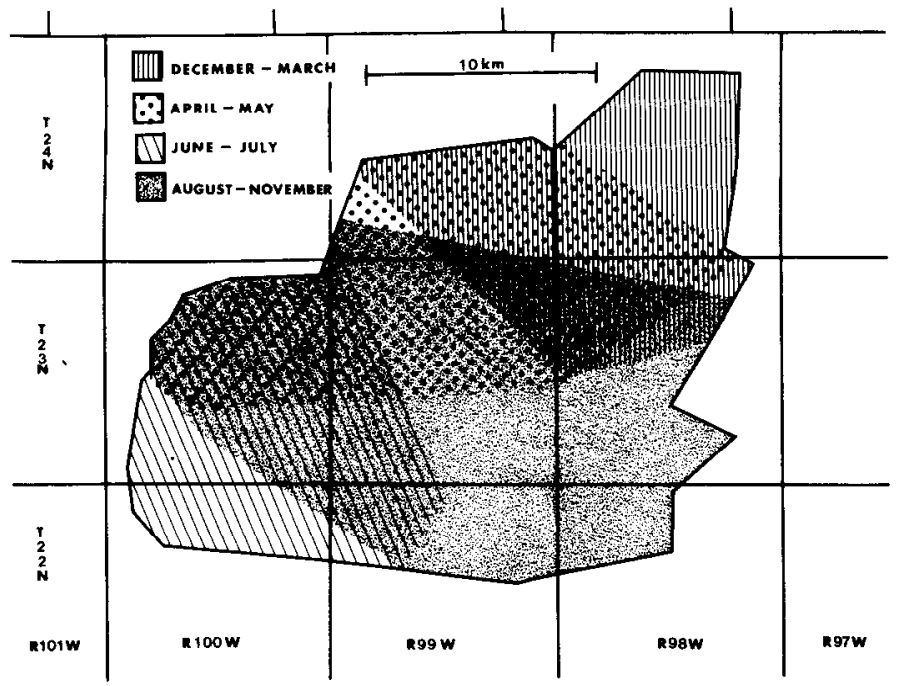

Fig. 2. A composite of the home ranges and seasonal locations of Herd \#l, Bands $A, B, H, L, A C$ and $C V$. weather conditions during those 2 seasons and the responses of the

Table 2. Dates of locations of bands from Herd \#1 at selected points in the Red Desert.

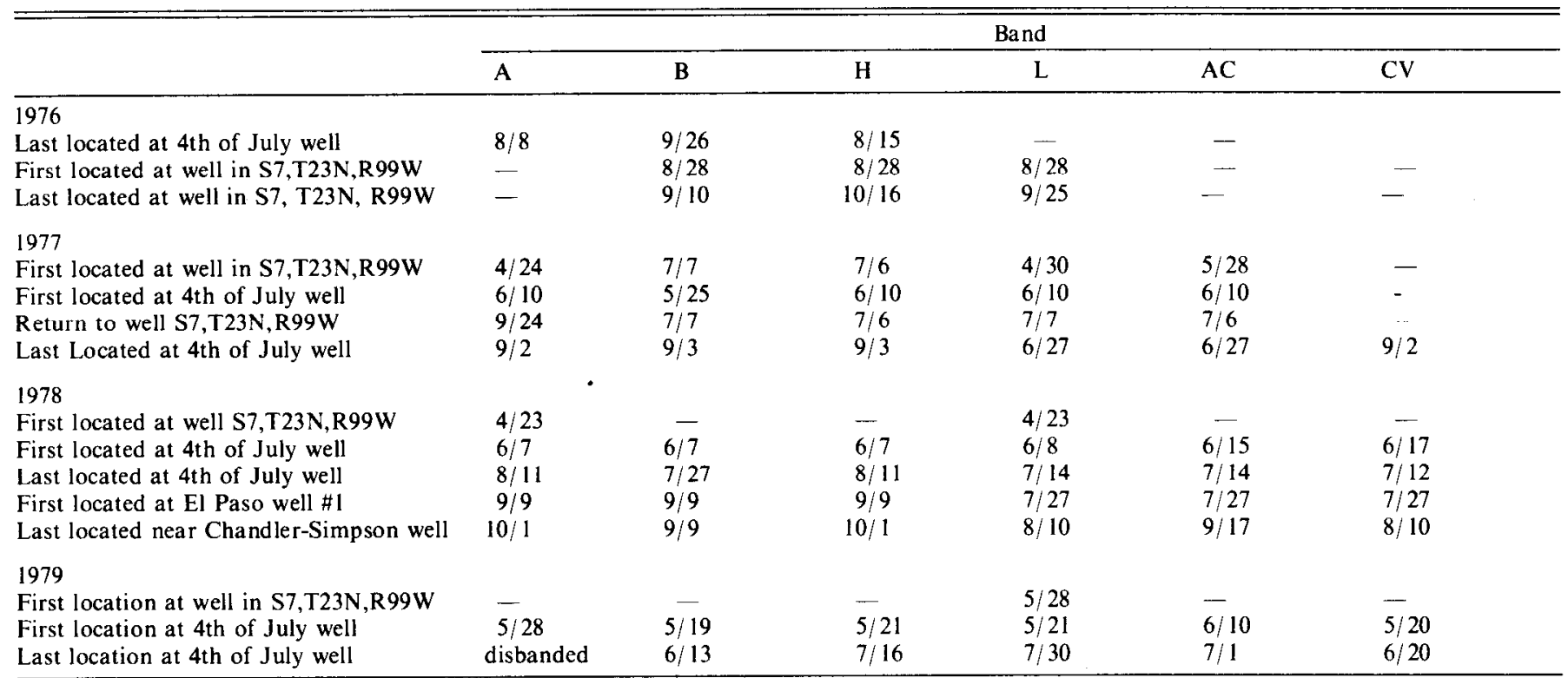

Dates given are those for locations and may not be the exact dates when bands arrived at or left any site, but they do serve to illustrate similarity and dissimilarity in the timing of movements for bands within one herd. 
horses to weather (Miller 1983).

\section{Discussion}

An interband dominance hierarchy has been described for the bands whose movements are reported here (Miller and Denniston 1979). Miller and Denniston (1979) suggested that a structured social unit made up of bands existed and defined that unit as a herd. The data presented here show that some of these same bands follow similar movement patterns within overlapping home horses. An expansion of the definition of a herd given in Miller and Denniston (1979) follows: a herd is a structured social unit made up of bands following similar movement patterns within a common home range. An examination of the home ranges presented in Green and Green (1977) and in Feist and McCullough (1976) suggests that herds may also be found in other feral horse populations.

Herds may be a deme or a breeding unit and could show significant morphological variation as found in demes of Uganda kob (Buechner and Roth 1974). Support for this idea is found in the variation in the proportion of certain coat colors seen in horses from different localities in the Red Desert. Pintos and greys, which are infrequently seen in the population as a whole, are common in certain areas.

Clutton-Brock and Harvey (1977 and 1978) suggested that large home ranges result where resources are strongly clumped. widely dispersed or unpredictable in abundance. Altmann (1974) and Crook et al. (1976) have predicted cxtensive home range overlap where several essential resources have very restricted distributions. Denham (1971) made a similar argument that clumping of populations should be high where predictability of resources is low. $W$ er sources and ridges which are used as cover in the Red Desert can be considered strongly clumped or as having restricted distributions and as being widely dispersed from one another. Marquiss (1957), stuaying vegetation composition and ground cover of relict areas in the sagebrush grassland type adjacent to my study area, found variations in ground cover and composition which were significant at the 0.01 level between sites and between years. From his data $I$ believe vegetation and hence forage in this section of the Red Desert may be considered both patchy and unpredictable in availability from year to year. If these factors are producing the large home range sizes, extensive home range overlap, and strongly clumped population distributions found in the Red Desert horses, then changes in the distribution and/or availability of resources can be expected to change home range and movement patterns.

Herds of horses, because they follow similar seasonal movement patterns and thus have similar habitat using patterns within a common home range, are logical management units for future feral horse mangement in the Red Desert.

\section{Literature Cited}

Altmann, S.A. 1974. Baboons, space, time and energy. Amer. Zool. 14:221-248.

Boyd, L.E. 1980. The natality, foal survivorship and mare-foal behavior of feral horses in Wyoming's Red Desert. M.S. thesis, Univ. Wyoming, Laramie.

Buechner, H.K., and H.D. Roth. 1974. The lek system in Uganda kob antelope. Amer. Zool. 14:145-162.

Clutton-Brock, T.H., and P.H. Harvey. 1977. Primate ecology and social organization. J. Zool. 183:1-39.

Clutton-Brock, T.H. and P.H. Harven. 1978. Mammals, resources and reproductive strategies. Nature 273:191-195.

Crook, J.H., J.E. Ellis, and J.D. Gross-Custard. 1976. Mammalian social systems: Structure and function. Anim. Behav. 24:261-274.

Denham W.W.1971. Energy relations and some basic properties of primate social organization. Amer. Anthropologist 73:77-95.

Feist, J.D., and D.R. McCullough. 1976. Behavior patterns and communication in feral horses. Z. Tierpsychol. 41:337-371.

Green, N.F., and H.D. Green. 1977. Wild horse population of Stone Cabin Valley, Nevada: A preliminary report. p. 59-65 In: Proc. National Wild Horse Forum. Coop. Exten. Serv., Univ. Nevada, Reno.

Marquiss, R.W. 1957. Vegetational composition and ground cover of some relict and grazed areas in the Red Desert of Wyoming. M.S. thesis, Univ. Wyoming, Laramie.

Miller, R. 1980. Band organization and stability in Red Desert feral horses. p. 113-123 In: Proc. Conf. Ecology and Behavior of Feral Equids, R.H. Denniston, ed. Univ. Wyoming, Laramie.

Miller, R. 1981. Male aggression, duminance and breeding behavior in Red Desert feral horses. Z. Tierpsychol. 57:340-351.

Miller, R. 1983. Habitat use of feral horses and cattle in Wyoming's Red Desert. J. Kange Manage. 36:195-199.

Miller, R., and R.H. Denniston. II. 1979. Interband dominance in feral horses. Z. Tierpsychol. 51:41-47.

Mohr, C.O. 1947. Table of equivalent populations of North American small mammals. Am. Midl. Nat. 37:223-249.

Welsh, D.A. 1975. Population, behavioral and grazing ecology of the horses of Sable Island, Nova Scotia. PH.D. thesis, Dalhousie Univ. 